\title{
Airway inflammation among compost workers exposed to actinomycetes spores
}

\author{
Kari Kulvik Heldal', Lene Madsø ${ }^{1}$, Wijnand Eduard' \\ ${ }^{1}$ National Institute of Occupational Health, Oslo, Norway
}

Heldal KK, Madsø L, Eduard W. Airway inflammation among compost workers exposed to actinomycetes spores. Ann Agric Environ Med. 2015; 22(2): 253-258. doi: 10.5604/12321966.1152076

\begin{abstract}
Objectives. To study the associations between exposure to bioaerosols and work-related symptoms, lung function and biomarkers of airway inflammation in compost workers.

Materials and method. Personal full-shift exposure measurements were performed on 47 workers employed at five windrow plants $(n=20)$ and five reactor plants $(n=27)$. Samples were analyzed for endotoxins, bacteria, fungal and actinomycetes spores. Health examinations were performed on workers and 37 controls before and after work on the day exposure was measured. The examinations included symptoms recorded by questionnaire, lung function by spirometry and nasal dimensions by acoustic rhinometry (AR). The pneumoproteins CC16, SP-D and SP-A were measured in a blood sample drawn at the end of the day.

Results. The levels of endotoxins (median $3 \mathrm{EU} / \mathrm{m}^{3}$, range $0-730 \mathrm{EU} / \mathrm{m}^{3}$ ) and actinomycetes spores (median $0.2 \times 10^{6} \mathrm{spores} / \mathrm{m}^{3}$, range $0-590 \times 10^{6}$ spores $/ \mathrm{m}^{3}$ ) were significantly higher in reactor plants compared to windrow plants. However, windrow composting workers reported more symptoms than reactor composting workers, probably due to use of respiratory protection. Exposure-response relationships between actinomycetes spores exposure and respiratory effects, found as cough and nose irritation during a shift, was significantly increased (OR 4.3, 95\% Cl 1.1-16, OR 6.1, 95\% Cl 1.5-25, respectively, $\mathrm{p}<0.05)$ among workers exposed to $0.02-0.3 \times 10^{6}$ actinomycetes spores $/ \mathrm{m}^{3}$, and $\mathrm{FEV} / \mathrm{FVC} \%$ decreased cross shift $(\mathrm{b}=-3.2$, $\mathrm{SE}=1.5 \%, \mathrm{p}<0.01$ ). Effects were weaker in the highest exposed group, but these workers used respiratory protection, frequently limiting their actual exposure. No relationships were found between exposure and pneumoprotein concentrations. Conclusions. The major agent in the aerosol generated at compost plants was actinomycetes spores which was associated with work related cough symptoms and work-shift lung function decrease.
\end{abstract}

Key words

exposure, actinomycetes spores, pneumoproteins, composting

\section{INTRODUCTION}

The introduction of industrial composting of organic household waste has resulted in health risks for an increasing number of workers. High exposure levels of microorganisms, organic dust and microbial components, have been reported in several studies $[1,2,3,4]$. So far, the health risks from exposure to bioaerosols at compost plants are not well understood, although both allergic as well as non-allergic symptoms and effects have been reported. Unspecific and toxic reactions, such as airway irritation and organic dust toxic syndrome (ODTS) have been observed $[5,6,7]$, as well as case reports of more adverse allergic respiratory diseases, such as hypersensitivity pneumonitis, allergic aspergillosis and asthma after excessively high exposure to microorganisms [8]. However, the causative agents in the compost dust remain unclear as the bioaerosol exposure assessments included few agents and few measurements. Comparisons between studies are further complicated by the use of different analytical methods.

An investigation was therefore conducted of exposure and health effects among workers in the Norwegian compost industry, including a more comprehensive exposure assessment with the focus on acute exposure-response associations. Also included were objective measures of

Address for correspondence: Kari Kulvik Heldal, Pb. 8149, N-0033 Oslo, Norway E-mail: Kari.heldal@stami.no

Received: 19 June 2014; accepted: 10 October 2014 pneumoproteins in serum as markers of lower airway injury, because in a previous study by the authors serum CC16 and SP-A was found to be associated with exposure to dry sewage dust [9]. Furthermore, the presented study included recording of symptoms, measurements of lung function and nasal dimensions, as well as measurements of personal exposure to inhalable dust, bacteria, fungal and actinomycetes spores and endotoxins. Associations between exposure and health effects were explored.

\section{MATERIALS AND METHOD}

Subjects. All 47 exposed workers employed in 10 compost plants in Norway were invited to participate in the study (participation 100\%). Twenty workers were employed at five windrow plants and 27 workers at five reactor plants. Controls $(n=37)$ were mainly white collar workers from the administration at the plants (Tab. 1). The study was approved by the Regional Medical Ethics Board. All participants gave their written informed consent.

Compost processes. Two processes were applied at the facilities for composting of household waste: reactor composting in closed reactors and windrow composting in long windrows (5 plants each). Reactor composting was mainly situated indoors and windrow composting mainly outdoors. The waste consisted mostly of source separated organic household waste, such as food and yard waste, but 
Table 1. Characteristics of the population

\begin{tabular}{llcc}
\hline & $\begin{array}{c}\text { Controls } \\
(\mathrm{N}=37)\end{array}$ & $\begin{array}{c}\text { Windrow } \\
\text { plants (N=20) }\end{array}$ & $\begin{array}{c}\text { Reactor plants } \\
(\mathrm{N}=27)\end{array}$ \\
\hline Age, AM (SD) & $43(10)$ & $41(9)$ & $42(11)$ \\
\hline Male, (\%) & 74 & 95 & 100 \\
\hline Atopy, (\%) & 26 & 10 & 26 \\
\hline Current smokers, (\%) & 16 & 50 & 44 \\
\hline $\begin{array}{l}\text { Tobacco consumption among } \\
\text { smokers, packyears, AM (SD) }\end{array}$ & $17(8)$ & $18(11)$ & $11(7)$ \\
\hline
\end{tabular}

$\mathrm{AM}=$ Arithmetic mean $(\mathrm{SD}=$ standard deviation)

also sludge from sewage plants and organic waste from food industries. The waste was stored indoors in processing halls and/or outdoors for several days, before mixing with structure material as ground up garden and wood waste. After the composting had ceased, the compost was shredded, sieved, and matured for up to several weeks. The workers operated bulldozers, cleaned and monitored humidity and oxygen in the compost.

Study design. All compost workers and unexposed controls underwent spirometry and acoustic rhinometry in the beginning and at the end of the work shift. Personal shift exposure was monitored during approximately six hours between the health examinations. The workers had not been exposed before the first health examination. A blood sample was collected after work. On the following two days after the health examinations additional personal exposure measurements were monitored to obtain more information about the exposure levels.

Questionnaires. The participants completed a selfadministered questionnaire which included questions on respiratory and gastro-intestinal symptoms experienced on the day of the exposure measurements. Smoking and health status was recorded by a general questionnaire [10].

Exposure. Two parallel personal filter samples were collected in PAS- 6 cassettes [11] using battery-powered pumps operated at $2.0 \mathrm{l} / \mathrm{min}$. One sample (polycarbonate filter, pore size $0.8 \mu \mathrm{m}$, Poretics, Osmonics, Livermore, USA) was analyzed for inhalable dust by gravimetry, for non-branching bacteria by fluorescence microscopy [12] and for fungal and actinomycetes spores by scanning electron microscopy (SEM) [13]. The second sample (glass fiber filter, Whatman GF/A, Maidstone, USA) was analyzed for endotoxin by a quantitative kinetic chromogenic Limulus amoebocyte lysate assay [14].

Spirometry. Pulmonary function was measured by spirometry (Vitalograph 2160 (SpirotracÒ, UK) according to the American Thoracic Society guidelines [15]. The same technician performed all tests. Spirometric airflow limitation was defined by a $\mathrm{FEV}_{1} / \mathrm{FVC}$ ratio $<70 \%$ and $\mathrm{FEV}_{1}<80 \%$ of predicted value based on ERS reference population [16].

Acoustic rhinometry. Dimensions of the nasal cavity were measured by acoustic rhinometry (Rhin2100, Rhino Metrics AS, Lynge, Denmark) as described in Rhinology [17]. The smallest total cross-sectional area and the total volume between 0-20 $\mathrm{mm}$ (1) and 20-50 $\mathrm{mm}$ (2) from the nostrils were labeled TMCA1 and TMCA2, and TVOL1 and TVOL2, respectively. Tests were performed before work, after work, and a third test was performed after work and 15 minutes after decongestion with Xyclometazolin. The degree of mucosal swelling was estimated from the decongestive effect [18]. A decongestion factor was computed as the ratio between the difference in volume before and after spraying and the volume before spraying.

Pneumoproteins. Blood samples were collected between 13:00-14:00, directly after personal exposure sampling was terminated. Whole blood was collected by venipuncture in $10 \mathrm{ml}$ tubes without additives (BD Diagnostic, Plymouth, UK). Serum was obtained after coagulation for 60 minutes at room temperature and centrifugation for 15 minutes at 3,000 RPM. The serum samples were then frozen in NUNC ${ }^{\circ}$ cryotubes at $-25^{\circ} \mathrm{C}$ within 2 hours, and kept frozen until analysis. Concentrations of the CC16, SP-A and SP-D were determined at the Department of Occupational and Environmental Medicine, University of Gothenburg, and analyzed as described previously [9].

Statistical methods. Distributions of exposure and outcome variables were described by arithmetic mean, standard deviation, median and range. Variables with positive skew were log-transformed before statistical testing with parametric methods. Spearman correlation coefficients $\left(r_{s}\right)$ were computed between exposure variables. Before exposure-response analysis continuous exposure variables were divided into a zero category (controls and 0 -values) and two categories with positive values of equal size. Exposureresponse associations and comparisons of job groups were tested by binary logistic and multiple linear regression models adjusted for age and tobacco consumption. Because of positivity problems with use of respiratory protection in the different job groups this variable was excluded from the models. Tobacco consumption for current smokers was characterized by pack-years in models of chronic effects and a dichotomous variable in models of cross-shift effects. The level of significance was set at 0.05 (two-tailed).

\section{RESULTS}

Exposure. Endotoxin and actinomycetes levels were significantly higher in reactor plants compared to windrow plants (Tab. 2). Exposure levels to inhalable dust, bacteria and fungal spores were more similar. Especially the exposure to actinomycetes during composting in reactor plants could reach high levels with a maximum measurement of $6 \times 10^{8}$ spores $/ \mathrm{m}^{3}$. However, in $20-30 \%$ of the samples no fungal or actinomycetes spores were detected. Strong positive correlations were found between dust, endotoxins and bacteria $\left(\mathrm{r}_{\mathrm{s}}=0.8-0.9, \mathrm{p}<0.001\right)$. There was no correlation between bacteria and actinomycetes $\left(r_{s}=-0.07\right)$.

Work-related symptoms. Table 3 shows symptoms reported by windrow and reactor plant workers compared to controls. The symptom prevalence adjusted for age and smoking were generally higher among compost workers compared to controls, and highest among windrow workers. Cough $(\mathrm{OR}=4.3,95 \% \mathrm{CI} 1.0-18.2)$ and any work-related symptom 
Table 2. Airborne contaminants in the inhalable aerosol fraction collected by personal sampling

\begin{tabular}{|c|c|c|c|c|c|c|c|c|c|c|c|c|}
\hline \multirow[b]{2}{*}{ Bioaerosol agent } & \multicolumn{12}{|c|}{ Bioaerosol exposure } \\
\hline & \multicolumn{4}{|c|}{$\begin{array}{l}\text { All measurements } \\
\text { in windrow plants }\end{array}$} & \multicolumn{4}{|c|}{ All measurements in reactor plants } & \multicolumn{4}{|c|}{$\begin{array}{l}\text { Measurements concomitant with health } \\
\text { examinations }\end{array}$} \\
\hline Inhalable dust (mg/m³) & 47 & 0.5 & 0 & $0.3(0.1-3.3)$ & 67 & 2.2 & 0 & $0.3(0.1-50)$ & 46 & 1.0 & 0 & $0.3(0.1-11)$ \\
\hline Endotoxin $\left(\mathrm{EU} / \mathrm{m}^{3}\right)$ & 35 & 4.0 & 0 & $2.0(0-25)^{*}$ & 59 & 38 & 0 & $3(0-730)^{*}$ & 44 & 22 & 0 & $3(0.7-310)$ \\
\hline Bacteria $\left(10^{6}\right.$ cells $\left./ \mathrm{m}^{3}\right)$ & 47 & 0.3 & 0 & $0.1(0-5.9)$ & 67 & 5.6 & 0 & $0.1(0-210)$ & 46 & 6.0 & 0 & $0.1(0-210)$ \\
\hline Fungal spores $\left(10^{6} \mathrm{spores} / \mathrm{m}^{3}\right)$ & 34 & 0.1 & 15 & $0.02(0-1.3)$ & 47 & 1.5 & 16 & $0.03(0-41)$ & 46 & 1.5 & 24 & $0.02(0-41)$ \\
\hline Actinomycetes $\left(10^{6}\right.$ spores $\left./ \mathrm{m}^{3}\right)$ & 34 & 0.4 & 11 & $0.2(0-5.6)^{* *}$ & 47 & 40.0 & 5 & $0.6(0-590)^{* *}$ & 46 & 23 & 20 & $0.2(0-590)$ \\
\hline
\end{tabular}

* $\mathrm{p}<0.01 \mathrm{t}$-test on log-transformed exposure data

${ }^{* *} \mathrm{p}<0.01$ Man-Whitney test

\# Number of values below detection limit

Table 3. Self reported symptoms in compost workers and controls adjusted for age and smoking

\begin{tabular}{|c|c|c|c|c|c|c|c|c|}
\hline \multirow{3}{*}{ Acute symptoms during work } & \multirow{2}{*}{\multicolumn{2}{|c|}{ Controls $(\mathrm{N}=37)$}} & \multicolumn{6}{|c|}{ Compost workers } \\
\hline & & & \multicolumn{2}{|c|}{ All $(\mathrm{N}=47)$} & \multicolumn{2}{|c|}{ Windrow plant $(\mathrm{N}=20)$} & \multicolumn{2}{|c|}{ Reactor plant $(\mathrm{N}=27)$} \\
\hline & Prevalence (\%) & OR & Prevalence (\%) & OR $(95 \% \mathrm{Cl})$ & Prevalence (\%) & OR $(95 \% \mathrm{Cl})$ & Prevalence (\%) & OR $(95 \% \mathrm{Cl})$ \\
\hline Nose irritation & 15 & Ref & 17 & $1.0(0.2-3.9)$ & 30 & $1.7(0.4-7.6)$ & 7 & $0.3(0.1-2.7)$ \\
\hline Eye irritation & 15 & Ref & 13 & $0.3(0.1-1.8)$ & 10 & $0.3(0.1-2.3)$ & 15 & $0.5(0.1-3.3)$ \\
\hline Upper airway irritation & 18 & Ref & 23 & $1.2(0.3-4.2)$ & 35 & $1.7(0.4-7.2)$ & 15 & $0.7(0.1-3.8)$ \\
\hline Asthma like symptoms & 6 & Ref & 17 & $1.9(0.3-11.6)$ & 20 & $2.1(0.3-16.9)$ & 15 & $2.0(0.3-16.0)$ \\
\hline Fever attacks & 0 & Ref & 0 & ND & 0 & ND & 0 & ND \\
\hline Nausea & 0 & Ref & 0 & ND & 0 & ND & 0 & ND \\
\hline Unusual tiredness & 18 & Ref & 26 & $0.7(0.2-2.8)$ & 30 & $1.1(0.3-5.4)$ & 22 & $0.3(0.1-2.6)$ \\
\hline One or more symptoms from the airways & 29 & Ref & 47 & $1.8(0.6-5.3)$ & 55 & $2.5(0.7-8.9)$ & 41 & $1.3(0.3-5.1)$ \\
\hline
\end{tabular}

$\mathrm{ND}=$ not done

The significant relationships $(p<0.05)$ are in bold

$(\mathrm{OR}=4.0,95 \%$ CI 1.1-14.7) among windrow workers were significantly more prevalent. Cough in reactor workers $(\mathrm{OR}=2.3)$ and asthma-like symptoms in both groups of compost workers $(\mathrm{OR}=2.0-2.1)$ were also elevated although not significant.

Spirometry. Table 4 summarizes lung function measures of controls and windrow and reactor plant workers. Predicted

Table 4. Lung function in compost workers and controls. Pre-shift values and cross-shift changes

\begin{tabular}{|c|c|c|c|c|c|}
\hline \multirow{3}{*}{\multicolumn{2}{|c|}{ Parameter }} & \multirow[b]{2}{*}{$\begin{array}{c}\text { Controls } \\
(\mathrm{N}=34)\end{array}$} & \multicolumn{3}{|c|}{ Compost workers } \\
\hline & & & All $(N=47)$ & $\begin{array}{l}\text { Windrow } \\
\text { plants } \\
(\mathrm{N}=20)\end{array}$ & $\begin{array}{l}\text { Reactor } \\
\text { plants } \\
(\mathrm{N}=27)\end{array}$ \\
\hline & & $\mathrm{AM}(\mathrm{SD})^{\mathrm{A}}$ & $\mathrm{AM}(\mathrm{SD})$ & $\mathrm{AM}(\mathrm{SD})$ & $\mathrm{AM}(\mathrm{SD})$ \\
\hline \multicolumn{6}{|l|}{ Pre-shift } \\
\hline & $\mathrm{FEV}_{1} \%$ pred & $100.8(11.7)$ & $95.6(13.2)$ & $95.8(14.2)$ & $95.5(12.7)$ \\
\hline & FVC \% pred & $109.5(10.3)^{a b}$ & $102.2(12.9)^{\mathrm{a}}$ & $102.1(14.7)$ & $102.3(11.6)^{b}$ \\
\hline & $\mathrm{FEV}_{1} / \mathrm{FVC} \%$ & $91.7(9.0)$ & $93.8(8.0)$ & $94.2(7.7)$ & $93.5(8.3)$ \\
\hline \multicolumn{6}{|c|}{ Cross-shift differences } \\
\hline & $\mathrm{FEV}_{1}$ & $0.01(0.1)$ & $0.01(0.1)$ & $-0.02(0.1)$ & $0.01(0.2)$ \\
\hline & FVC & $0.03(0.2)$ & $0.04(0.2)$ & $0.09(0.2)$ & $0.01(0.1)$ \\
\hline & $\mathrm{FEV}_{1} / \mathrm{FVC}_{0}$ & $-0.16(2.7)$ & $-0.50(3.2)$ & $-1.54(2.9)$ & $0.23(3.3)$ \\
\hline
\end{tabular}

$\mathrm{AM}=$ Arithmetic mean. $\mathrm{SD}=$ standard deviation

a: General linear model test between controls and workers adjusted for smoking, age and atopy $\mathrm{p}<0.05_{\text {, }}$ : : between reactor workers and controls, $\mathrm{p}<0.05$
FVC\% measured before work for all compost workers (102.2\%) and for the reactor plant workers only (102.3\%), was lower compared to controls (109.5\%) adjusted for packyears, age and atopy $(\mathrm{p}<0.05)$. The difference in FVC\% among smoking controls and workers $(118.0 \%-100.7 \%)$ was substantially larger than among non smokers (108.7\% - 103.5\%).

Pneumoproteins. The serum concentrations of SP-A, SP-D and CC16 are shown in Table 5. CC16 was lower among windrow plant workers $(5.6 \mathrm{ng} / \mathrm{ml})$ compared to controls $(6.4 \mathrm{ng} / \mathrm{ml})$ and reactor plant workers $(6.3 \mathrm{ng} / \mathrm{ml})$, but not significantly.

Acoustic rhinometry. The outer volume of the nasal cavity TVOL1 showed a significant cross- shift decrease in volume during the work shift among workers at the reactor plant $\left(-0.28 \mathrm{~cm}^{3}, \mathrm{p}<0.01\right)$, adjusted for smoking and age, and also among all compost workers combined $\left(-0.22 \mathrm{~cm}^{3}, \mathrm{p}<0.05\right)$ (data not shown). Adjusted cross-shift changes in controls $\left(-0.13 \mathrm{~cm}^{3}\right)$ and windrow compost workers $\left(-0.13 \mathrm{~cm}^{3}\right)$ were smaller but not significant. No significant cross-shift changes were observed for the inner dimensions of the nose. Decongestion factors, both for the exposed groups (0.69) and controls (0.70), were at the higher end of the range indicated for moderate congestion from $0.4-0.7$ [18].

Respirator use. Dust masks were used during 26\% of all measurements, $41 \%$ (11 workers) during work at the reactor 
Table 5. The concentrations of serum pneumoproteins in compost workers and controls

\begin{tabular}{|c|c|c|c|c|c|c|c|c|}
\hline \multirow{3}{*}{$\begin{array}{l}\text { Pneumo- } \\
\text { proteins }\end{array}$} & \multirow{2}{*}{\multicolumn{2}{|c|}{ Controls $(\mathrm{N}=37)$}} & \multicolumn{6}{|c|}{ Compost workers } \\
\hline & & & \multicolumn{2}{|c|}{ All $(\mathrm{N}=47)$} & \multicolumn{2}{|c|}{ Windrow plants $(\mathrm{N}=20)$} & \multicolumn{2}{|c|}{ Reactor plants $(\mathrm{N}=27)$} \\
\hline & AM & Med (range)* & $\mathrm{AM}$ & Med (range) & $\mathrm{AM}$ & Med (range) & AM & Med (range) \\
\hline $\mathrm{SP}-\mathrm{A}, \mu \mathrm{g} / \mathrm{ml}$ & 280 & $50(1-2800)$ & 145 & $40(0-14600)$ & 100 & $43(1-480)$ & 180 & $38(3-1460)$ \\
\hline SP-D, ng/ml & 108 & $95(36-234)$ & 110 & $105(35-219)$ & 101 & $102(36-150)$ & 115 & $111(35-219)$ \\
\hline $\mathrm{CC} 16, \mathrm{ng} / \mathrm{ml}$ & 6.4 & $6.0(3.0-17)$ & 6.2 & $5.7(1.7-13)$ & 5.6 & $5.3(1.7-13)$ & 6.3 & $6.0(3.1-13)$ \\
\hline
\end{tabular}

* Arithmetic mean, median and range

plants and 5\% (1 worker) during work at the windrow plants. As expected, dust masks were used much more frequently during measurements in the highest exposure category than in the lower. For actinomycetes spores, 63\% in the highest exposed category used respirators and only $7 \%$ in the lowest exposed category, for endotoxins 36\% and 14\%, respectively. They were all workers at the reactor plants. The actual exposure of the reactor workers must therefore have been substantially lower.

Associations between exposure and health effects. The symptoms of nose irritation, upper airway irritation, cough, one or more airway symptoms and one or more work related symptoms, were significantly higher in the middle exposure category of actinomycetes spores $\left(0.02-0.3 \times 10^{6} / \mathrm{m}^{3}\right)$ measured on the same day of the health examination (Tab. 6), but not for the highest exposed category. Cough was also associated with middle category exposure to bacteria (0.01$0.2 \times 10^{6} / \mathrm{m}^{3}$ ), endotoxins at exposure level $0.7-2.7 \mathrm{EU} / \mathrm{m}^{3}$ and dust at exposure level $0.1-0.3 \mathrm{mg} / \mathrm{m}^{3}$. Among workers higher exposed to fungal spores $\left(0.1-41 \times 10^{6} / \mathrm{m}^{3}\right)$ an association was found with tiredness during the day.

A significant cross-shift change in $\mathrm{FEV}_{1} / \mathrm{FVC} \%$ was observed in the middle exposure category of actinomycetes spores $(b=-3.2 \%, S E=1.5 \%, p=0.003)$, and close to significant for the highest exposed category $(b=-1.3 \%, S E=0.7 \%, p=0.08)$ adjusted for age and smoking. Statistical adjustment for respiratory protection was not possible because no controls, one person in the middle exposed category but 10 persons in the highest exposed category, used respirators.

No associations were observed between the serum level of pneumoproteins, nasal cavity measurements and exposure to any agent.

\section{DISCUSSION}

The most important agent for respiratory effects among compost workers were spores from the Gram-positive actinomycetes showing significantly increased point prevalence of cough and cross- shift lung function decline when exposed to $0.02-0.3 \times 10^{6}$ actinomycetes spores $/ \mathrm{m}^{3}$. Especially reactor plant workers could be exposed to high levels of actinomycetes (maximum $590 \times 10^{6}$ spores $/ \mathrm{m}^{3}$ ). These workers were exposed to higher levels of both actinomycetes and endotoxins than workers at the windrow plants. However, the use of respiratory protection may have reduced actual exposure substantially. This probably confounded exposureresponse associations and may explain the seemingly lower risk for respiratory effects in workers in the highest exposure category and in reactor workers. The cross-shift decline of $\mathrm{FEV}_{1} / \mathrm{FVC}$ indicates that exposure to actinomycetes spores induces an inflammatory reaction in the lower airways. Associations between cough and exposure were also found

Table 6. Odds ratios and $95 \%$ confidence intervals $(95 \% \mathrm{Cl})$ of acute symptoms for individual exposure variables adjusted for age and smoke

\begin{tabular}{|c|c|c|c|c|c|c|c|}
\hline \multirow{2}{*}{$\begin{array}{l}\text { Exposure } \\
\text { Agent }\end{array}$} & \multirow[b]{2}{*}{ Concentration } & \multicolumn{6}{|c|}{ Odds ratio $(95 \% \mathrm{Cl})$} \\
\hline & & $\begin{array}{l}\text { Nose } \\
\text { irritation }\end{array}$ & $\begin{array}{l}\text { Upper airway } \\
\text { irritation }\end{array}$ & Cough & Tiredness & $\begin{array}{c}\text { One or more } \\
\text { airway symptoms }\end{array}$ & $\begin{array}{c}\text { One or more } \\
\text { work symptoms }\end{array}$ \\
\hline \multirow{3}{*}{$\begin{array}{l}\text { Actinomycetes, } \\
10^{6} \text { spores } / \mathrm{m}^{3}\end{array}$} & 0 & REF & REF & REF & REF & REF & REF \\
\hline & $0.02-0.3$ & $6.1(1.5-25)$ & $6.2(1.5-25)$ & $4.3(1.1-16)$ & $0.8(0.2-3.5)$ & $3.8(1.1-13)$ & $4.5(1.2-17)$ \\
\hline & $0.5-590$ & $0^{*}$ & $0^{*}$ & $2.4(0.6-9.1)$ & $2.7(0.8-9.8)$ & $1.0(0.3-3.6)$ & $1.7(0.5-5.5)$ \\
\hline \multirow{3}{*}{$\begin{array}{l}\text { Fungal spores, } \\
10^{6} \text { spores } / \mathrm{m}^{3}\end{array}$} & 0 & REF & REF & REF & REF & REF & REF \\
\hline & $0.01-0.06$ & $1.0(0.2-4.6)$ & $1.1(0.3-4.7)$ & $0.7(0.2-3.1)$ & $1.0(0.2-4.7)$ & $1.0(0.3-3.7)$ & $1.2(0.3-4.3)$ \\
\hline & $0.07-41$ & $0.4(0.1-3.2)$ & $0.6(0.1-3.2)$ & $2.4(0.7-8.7)$ & $4.0(1.1-15)$ & $1.9(0.5-6.4)$ & $3.2(0.9-12)$ \\
\hline \multirow{3}{*}{$\begin{array}{l}\text { Bacteria, } \\
10^{6} \text { cells } / \mathrm{m}^{3}\end{array}$} & 0 & REF & REF & REF & REF & REF & REF \\
\hline & $0.01-0.2$ & $1.2(0.3-4.9)$ & $1.4(0.4-5.3)$ & $3.9(1.1-14)$ & $0.9(0.2-3.7)$ & $2.9(0.9-9.2)$ & $2.9(0.9-9.1)$ \\
\hline & $0.2-210$ & $0.4(0.1-2.4)$ & $0.5(0.1-2.6)$ & $2.1(0.6-7.9)$ & $1.9(0.5-6.7)$ & $1.3(0.4-4.3)$ & $2.9(0.0-9.2)$ \\
\hline \multirow{2}{*}{$\begin{array}{l}\text { Endotoxins, } \\
\mathrm{EU} / \mathrm{m}^{3}\end{array}$} & 0 & REF & REF & REF & REF & REF & REF \\
\hline & $2.9-310$ & $0.5(0.1-2.9)$ & $1.0(0.2-4.3)$ & $3.4(0.9-13)$ & $0.9(0.2-3.4)$ & $1.6(0.5-5.1)$ & $2.1(0.7-6.4)$ \\
\hline \multirow{3}{*}{$\begin{array}{l}\text { Dust, } \\
\mathrm{mg} / \mathrm{m}^{3}\end{array}$} & 0 & REF & REF & REF & REF & REF & REF \\
\hline & $0.1-0.3$ & $1.5(0.5-6.2)$ & $1.8(0.6-7.1)$ & $4.9(1.3-19)$ & $0.8(0.2-3.5)$ & $2.9(0.9-9.4)$ & $2.8(0.9-9.0)$ \\
\hline & $0.4-11$ & $0.3(0.1-2.2)$ & $0.4(0.1-1.9)$ & $2.3(0.6-9.0)$ & $2.3(0.6-8.9)$ & $1.1(0.3-3.8)$ & $2.4(0.7-7.7)$ \\
\hline
\end{tabular}


for dust, bacteria and endotoxins, but because exposure levels of actinomycetes spores were weakly correlated with endotoxins and bacteria, the observed exposure-response associations found for actinomycetes spores can be regarded as independent.

The statistical power of this study was limited by the small size of the respondents. A strength of the cross-shift study design is that exposure is measured simultaneously with acute effects, and was estimated more accurately than in studies of chronic effects where cumulative exposure has to be estimated over often long time periods. Mass significance was also considered as 30 associations were tested, and two of the present associations are likely to be found with a statistical probability of 0.05 . Nine significant associations were observed, indicating that the majority of the findings were significant.

The present study deviates from published studies by the lower levels of endotoxins and fungal spores and higher levels of actinomycetes spores. Exposure levels of actinomycetes spores during composting are poorly described in the literature, and studies are difficult to compare because different analytical methods were used. Exposure levels of actinomycetes spores during composting in Finnish $\left(3-20 \times 10^{3} \mathrm{cfu} / \mathrm{m}^{3}\right)$ [20] and German composting sites (4$\left.3,500 \times 10^{3} \mathrm{cfu} / \mathrm{m}^{3}\right)[6]$ using culture-based methods have been reported, also exposure to endotoxins, viable microorganisms and fungal spores (Aspergillus and Penicillum species) [2, $4,5,7]$. Culture-based methods measure generally lower concentrations than counting of both viable and dead cells by microscopic methods. However, exposure levels of culturable fungi of $2-10 \times 10^{6} \mathrm{cfu} / \mathrm{m}^{3}$ have been reported [6] which are more than 100 times higher than the median level of $0.02 \times 10^{6}$ spores $/ \mathrm{m}^{3}$ in the present study. On the other hand, some measurements exceeded the proposed effect level of $10^{5}$ fungal spores $/ \mathrm{m}^{3}$ by far [21], showing a maximum value of $40 \times 10^{6} \mathrm{spores} / \mathrm{m}^{3}$. Also, exposure to endotoxins, especially during composting at windrow plants, was low $\left(0-25 \mathrm{EU} / \mathrm{m}^{3}\right)$ in this study, compared to Dutch compost workers which were exposed from $2-1,900 \mathrm{EU} / \mathrm{m}^{3}[2,3,4]$.

There is also limited information available of the health effects in compost workers. A review by Schlosser et al. (2009) concluded that health effects in exposed compost workers include both inflammatory and allergic outcomes, and primarily respiratory effects [22]. Endotoxin is suggested as the major causal agent of the upper airway inflammatory responses, while there is suggestive evidence from case studies among compost workers of an association between exposure to fungal and actinomycetes spores [22]. In the present study, irritation symptoms from the upper airways and cough were associated with exposure to actinomycetes (range $0.02-3 \times 10^{6} / \mathrm{m}^{3}$ ), and an association was also found between cough and other agents in the aerosol, such as endotoxins (0.7-2.7 EU/m $\left.{ }^{3}\right)$. However, endotoxin exposure is not likely to be causal because endotoxin levels were low and similar to indoor air environments $\left(0.05-11 \mathrm{EU} / \mathrm{m}^{3}\right)$ [23]. As endotoxin, bacteria and dust agents were strongly correlated, other agents in the aerosol may be involved.

Nose and cough symptoms were reported with high prevalence (57-70\%) among 26 Dutch compost workers, but no exposure associations with endotoxin exposure (100$3500 \mathrm{EU} / \mathrm{m}^{3}$ ) were found [3]. Bünger et al. (2007) concluded in a 5-year follow-up study of 123 compost workers that exposure to organic dust at work-places of composting facilities was associated with adverse acute and chronic respiratory health effects, including upper airway irritation and chronic bronchitis [6]. Exposure measurements revealed high levels of actinomycetes spores in the study $\left(3.5 \times 10^{6} \mathrm{cfu} / \mathrm{m}^{3}\right)$. However, measurements were performed only in 6 of the 41 composting sites and showed large variability [6]. In the presented study it was found that exposure to median level of actinomycetes spores $\left(0.02-0.3 \times 10^{6}\right.$ spores $\left./ \mathrm{m}^{3}\right)$ was associated with cough. The association was not significant in the highest exposed group $\left(0.5-590 \times 10^{6}\right.$ spores $\left./ \mathrm{m}^{3}\right)$, but respiratory protection was prevalent in this group.

Nasal swelling in the outer section of the nasal cavity was observed among the compost workers, which was greatest among reactor workers. No swelling of the inner part of the nose was observed. The inner part mucosa extends over a larger surface area than the outer section, which is therefore regarded as a more accurate measure of inflammatory response. The present finding of nasal swelling in the outer section suggests exposure to very large particles that deposit in the nose. Cross-shift swelling in the outer part has been reported previously in workers exposed to sewage dust [24].

Compost workers showed significantly lower predicted FVC\% compared to controls, and a lower $\mathrm{FEV}_{1} / \mathrm{FVC}$ was indicated. The largest difference was observed among smokers, indicating that smokers may be more sensitive to the exposure. However, there were few smokers in the control group. Also, Bünger et al. (2007) reported an accelerated decline $(-5.4 \%)$ in predicted FVC\% during a 5-year follow-up period of 123 compost workers [6]. In contrast, no decline in lung function was found among 26 Dutch compost workers [2] exposed to higher levels of endotoxins (100-3,500 EU/m $\left.{ }^{3}\right)$ compared to the current study. Schlosser et al. concluded in a review of 20 epidemiological studies of compost workers that results pertaining to respiratory function decrease are conflicting, but that findings may be limited by a weak statistical power due to small study populations [22].

\section{CONCLUSIONS}

In conclusion, exposure to actinomycetes spores was associated with work-related nasal and cough symptoms and cross-shift decline in lung function among compost workers. Even though workers at reactor plants had a higher external exposure than the windrow workers, fewer respiratory symptoms and effects were observed, most likely due to use of respiratory protection. The associations between exposure to actinomycetes spores and respiratory effects mainly found among windrow workers seem therefore more reliable.

\section{REFERENCES}

1. Heldal KK, Eduard W, Bergum M. Bioaerosol exposure during handling of source separated household waste. Ann Agric Environ Med. 1997; 4: $45-51$.

2. van Tongeren M, van Amelsvoort L, Heederik D. Exposure to organic dust, endotoxins, and microorganisms in the municipal waste industry. Int J Occup Environ Health. 1997; 3: 30-36

3. Douwes J, Wouters IM, Dubbeld H, van Zwieten, Steerenberg P, Doekes $\mathrm{G}$ et al. Upper airway inflammation assessed by nasal lavage in compost workers: A relation with bio-aerosol exposure. Am J Ind Med. 2000; 37: 459-468.

4. Wouters IM, Spaan S, Douwes J, Duekes G, Heederik D. Overview of personal occupational exposure levels to inhalable dust, endotoxins, 
$\beta(1-3)$-glucan and fungal extracellular polysaccharides in the waste management chain. Am Occup Hyg. 2006; 50: 39-53.

5. Bünger J, Antlauf-Lammers M, Schulz TG, Westphal GA, Müller MM, Ruhnau P et al. Health complaints and immunological markers of exposure to bioaerosols among biowaste collectors and compost workers. Occup Environ Med. 2000; 57: 458-464.

6. Bünger J, Schappler-Scheele B, Hilgers R, Haallier E. A 5-year follow-up study on respiratory disorders and lung function in workers exposed to organic dust from composting plants. Int Arch Environ Health. 2007; 80: 306-312.

7. Domingo JL, Nadal M. Domestic waste composting facilities: A review of human health risks. Environment International 2009; 35: 382-389.

8. Poole CJM, Wong M. Allergic bronchopulmonary aspergillosis in garden waste (compost) collectors- occupational implications. Occup Med. 2013; 63: 517-519.

9. Heldal KK, Barregard L, Larsson P, Ellingsen D. Pneumoproteins in sewage workers exposed to sewage dust. Int Arch Occup Environ Health. 2013; 86: 65-70.

10. Melbostad E, Eduard W, Skogstad A, Sandven P, Lassen J, Søstrand P, et al. Exposure, symptoms and airway inflammation among sewage workers. Am J Ind Med. 1994; 25: 59-63.

11. Van der Wal JF. Comparative measurements of the total dust concentration at the work place with different samplers - part 1. StaubReinhalt Luft. 1983; 43: 292-294 (in German).

12. Heldal K, Skogstad A, Eduard W. Improvements in the Quantification of Airborne Micro-organisms in the Farm Environment by Epifluorescence Microscopy. Ann Occup Hyg. 1996; 40: 437-447.

13. Eduard W, Sandven P, Johansen B, Bruun R. Identification and quantification of mould spores by scanning electron microscopy (SEM). Ann Occup Hyg. 1988; 32: 447-445.
14. Douwes J, Versloot P, Hollander A, Heederik D, Doekes G. Influence of various dust sampling extraction methods on the measurements of endotoxin. Appl Environ Microbiol. 1995; 61: 1763-1769.

15. American Thoracic Society. Standardisation of spirometry - 1987 update. Am Rev Respir Dis. 1987; 136: 1285-1298.

16. British Thoracic Society. Guidelines for the management of chronic obstructive pulmonary disease. Thorax 1997; 5: 1-26.

17. Anon. Acoustic rhinometry - standardization and use. Rhinology 2000; (Suppl. 16.).

18. Mamikogulu B, Houser SM, Corey JP. An interpretation method for objective assessment of nasal congestion with acoustic rhinometry. Laryngoschope 2002; 112: 926-929.

19. ATS/ERS Recommendations for standardized procedure for the online and offline measurement of exhaled lower respiratory Nitric Oxide and Nasal Nitric Oxide. Am J Crit Care Med. 2005; 171: 912-930.

20. Tolvanen O, Nykänen J, Nivukoski A, Himanen M, Veijanen A, Hänninen K. Occupational hygiene in a Finnish drum composting plant. Waste Management 2005; 25: 427-433.

21. Eduard W. Fungal spores: a critical review of the toxicological and epidemiological evidence as a basis for occupational exposure limit setting. Crit Rev Toxicol. 2009; 39: 799-864.

22. Schlosser O, Huyard A, Cartnick K, Yañez A, Catalán V, Quang ZD. Bioaerosol in composting facilities: Occupational health risk assessment. Water Environ Res. 2009; 81: 866-877.

23. Singh U, Levin L, Grinsphun A, Schaffer C, Adhikari A, Reponen T. Influence of home characteristics on airborne and dustborn endotoxin and $\beta_{- \text {- }}$ glucan. J Environ Monit. 2011; 13: 3246-3253.

24. Heldal KK, Madsø L, Huser PO, Eduard W. Exposure, symptoms and airway inflammation among sewage workers. Ann Agric Environ Med. 2010; 17: 263-268. 